\title{
IMPLANTATION IN RATS TREATED NEONATALLY WITH TESTOSTERONE PROPIONATE
}

\author{
M. A. KRAMEN* \\ Department of Physiology, University of Kansas Medical School, \\ Kansas City, Kansas, U.S.A.
}

(Received 9th September 1973)

Although a previous study (Kramen, 1969) demonstrated normal uterine decidual sensitivity in young female rats which had been given low $(50 \mu \mathrm{g})$ doses of testosterone propionate (TP) shortly after birth, it is not known if uterine sensitivity to blastocyst implantation is normal in such rats. The present study was undertaken to determine if the uteri of adult rats treated neonatally with TP could support implantation.

Female Holtzman rats were treated on Day 5 of life with $50 \mu \mathrm{g}$ TP as previously described (Kramen \& Johnson, 1971). Various hormonal treatments were used to induce implantation in 100- to 120-day-old TP-treated rats which were mated after ovulation had been induced. In one group, the progesterone necessary to maintain pregnancy was supplied by supporting corpora lutea with a normal female pituitary implanted beneath the kidney capsule (NikitovichWiner \& Everett, 1958). Laparotomy was performed 2 weeks after the transplant to check for the presence of corpora lutea. If they were absent, $10 \mu \mathrm{g}$ NIH-LH-S11 was given intravenously to induce ovulation. The females were mated the same night and the presence of spermatozoa in the vaginal smear the following morning (Day 1) was taken to indicate that conception had occurred. Oestradiol benzoate (EB) was administered from Days 4 to 13. Two other groups of rats similarly treated with TP and subsequently mated after ovulation had been induced were injected subcutaneously with progesterone or progesterone and EB in $0.1 \mathrm{ml}$ sesame oil. All animals were killed on Day 14 and the numbers of implantations and feto-placental weights were recorded.

All animals had ten or more corpora lutea. Placental sites were present on Day 14 in $64 \%$ of Group- 1 females treated with TP, but the number of implantations was generally low (Table 1). Only one animal had a normal number (nine) of embryos. This animal exhibited asynchronous implantation. The weights of the combined fetuses and placentae indicated normal implantation of three embryos and delayed implantation of the remaining six. The development of the latter was estimated to be equivalent to that of normal embryos on Day 10 of pregnancy (Greenwald \& Johnson, 1968). No gross abnormalities were observed in these embryos. The remaining animals of Group 1 had few implantations and there were also indications of delayed development. The hor-

\footnotetext{
* Present address: Departments of Obstetrics and Gynecology and Anatomy, The University of Texas Health Science Center at San Antonio, San Antonio, Texas 78284, U.S.A.
} 
monal regimens tried in Groups 2 and 3 were unsuccessful in inducing implantation. Progesterone alone failed to maintain blastocysts in a state of delayed implantation and none could be recovered from the uteri on Day 14. Since progesterone maintains blastocysts in a state of delayed implantation in ovariectomized rats until oestrogen is administered, it is likely that the intact pituitary and ovary contributed to the failure of implantation in these groups (Mayer, 1963; Nutting \& Meyer, 1963; Psychoyos, 1967). Occasionally, however, implantation will occur with injections of progesterone alone. Most of the implantations observed in rats treated with $\mathrm{TP}$ were not evenly spaced within the uterus, but were crowded near the cervix. In normal female rats, this phenomenon has been associated with the administration of $2.5 \mu \mathrm{g}$, or more, of oestrone on any of the first 4 days of pregnancy (Haddad \& Ketchel, 1969).

Table 1. Implantation following induced ovulation in rats treated neonatally with testosterone propionate

\begin{tabular}{|c|c|c|c|c|c|}
\hline Group & $\begin{array}{l}\text { Testosterone } \\
\text { propionate } \\
(\mu \mathrm{g})\end{array}$ & $\begin{array}{c}\text { No. of animals } \\
\text { with } \\
\text { implantations }\end{array}$ & $\begin{array}{l}\text { Mean no. of } \\
\text { implantations } \\
\text { lanimal } \\
\pm S . E .\end{array}$ & $\begin{array}{c}\text { * Mean wt of } \\
\text { implantations } \\
\text { on Day } 14(\mathrm{mg}) \\
\pm S . E .\end{array}$ & Treatment \\
\hline 1 & 50 & $9 / 14$ & $4 \cdot 1 \pm 0 \cdot 8$ & $\begin{array}{c}140 \cdot 5 \pm 8 \cdot 9(26) \dagger \\
\text { and } \\
690 \cdot 0 \pm 12 \cdot 4(3)\end{array}$ & $\begin{array}{l}\text { Pituitary implant } \\
\text { and } 0 \cdot 1 \mu \mathrm{g} \mathrm{EB} \\
\text { on Days } 4 \text { to } 13\end{array}$ \\
\hline 2 & 50 & $0 / 7$ & 0 & - & $\begin{array}{l}2 \mathrm{mg} \text { progesterone } \\
+0.1 \mu \mathrm{g} \mathrm{EB} \text { on } \\
\text { Days } 1 \text { to } 13\end{array}$ \\
\hline 3 & 50 & $1 / 6$ & $1 \cdot 0$ & 一 & $\begin{array}{l}2 \mathrm{mg} \text { progesterone } \\
\text { on Days } 1 \text { to } 13\end{array}$ \\
\hline 4 & Normal & $8 / 8$ & $12 \cdot 2 \pm 0 \cdot 4$ & $550 \cdot 8 \pm 9 \cdot 1(98)$ & None \\
\hline
\end{tabular}

* Combined weight of feto-maternal unit.

$\uparrow$ No. of individual values given in parentheses.

The fetuses in these rats were also smaller than normal. A decrease of uterine sensitivity to trauma beyond the optimal time of implantation has been shown to restrict decidualization to the cervical region (von Berswordt-Wallrabe, Geller \& Herlyn, 1964; Herlyn, 1968).

The failure to achieve a higher implantation rate in Group-1 rats may have been due to the continued administration of EB after Day 4. Carpent \& Desclin (1967), using pituitary transplants in hypophysectomized rats, noted implantation of normal numbers of embryos in 61 to $76 \%$ of animals given a single injection of $0.25 \mu \mathrm{g}$ EB. They saw no evidence of asynchronous implantation. When, however, the same dose was repeatedly injected from the 4th day with or without exogenous progesterone, there was a failure of normal implantation. A striking difference was observed if oestrone rather than EB was used. After a single injection of $0.25 \mu \mathrm{g}$ EB on Day 1, normal numbers of embryos implanted in all rats given $1 \mu \mathrm{g}$ oestrone and $4 \mathrm{mg}$ progesterone from the 4th day. Whereas implantation will occur and pregnancy will be supported in normal rats following the administration of $2 \mathrm{mg}$ progesterone and $1 \mu \mathrm{g}$ oestrone from Day 1 to Day 12, failure of implantation using EB rather than 
oestrone in rats treated with TP must be attributed to the greater oestrogenicity of EB (Carpent \& Desclin, 1967; Ahmad, 1968). The failure of embryos to implant in rats treated with TP seems, therefore, to be a function of the continued administration of oestrogen, exerting an inhibitory effect on decidualization of the uterus.

While these results do not demonstrate the occurrence of a normal pregnancy in rats previously treated with $50 \mu \mathrm{g} \mathrm{TP}$ on the 5 th day of life, evidence has been presented that the uteri of such females respond to blastocysts with normal implantation. Failure of a normal number of embryos to implant probably results from sub-optimal hormonal therapy rather than the absence of uterine sensitivity.

\section{REFERENCES}

Ahmad, N. (1968) The ovaries of hypophysectomized rats maintained on estrone and progesterone for 12 days of gestation do not, thereafter, support pregnancy to term. Anat. Rec. 160, 457.

Garpent, G. \& Desclin, L. (1967) Progress of pregnancy and foetal morphology after early pituitary transplantation and hormonal therapy in the rat. Acta endocr., Copenh. 55, 10.

Greenwald, G. S. \& Johnson, D. C. (1968) Gonadotropic requirements for the maintenance of pregnancy in the hypophysectomized rat. Endocrinology, 83, 1052.

Haddad, V. \& Ketchel, M. M. (1969) Termination of pregnancy and occurrence of abnormalities following estrone administration during early pregnancy. Int. F. Fert. 14, 56.

Herlyn, U. (1968) Animal experiments on decidualization and nidation. Z. Geburtsh. Gynäk. 168, 156.

KRAMEN, M. A. (1969) Reproduction and ovum viability in the anovulatory, androgen-induced, persistent-estrus rat. Thesis, University of Kansas, Kansas City.

Kramen, M. A. \& Johnson, D. C. (1971) Mating, fertilization, and ovum viability in the anovulatory, persistent-estrus rat. Fert. Steril. 22, 745.

MAYER, G. (1963) The experimental control of ovum implantation. In Techniques in Endocrine Research, p. 245. Eds. P. Eckstein and F. Knowles. Academic Press, New York.

Nikitovich-Winer, M. \& Everett, J. W. (1958) Comparative study of luteotropin secretion by hypophysial autotransplants in the rat. Effects of site and stages of the estrous cycle. Endocrinology, $62,522$.

Nutting, E. F. \& Meyer, R. K. (1963) Implantation delay, nidation and embryonal survival in rats treated with ovarian hormones. In Delayed Implantation, p. 233. Ed. A. C. Enders. University of Chicago Press.

Psychoyos, A. (1967) Implantation in the rat. In Advances in Reproductive Physiology, Vol. 2, p. 257. Ed. A. McLaren. Logos Press, London.

von Berswordt-Wallrabe, I., Geller, H. F. \& Herlyn, U. (1964) Temporal aspects of decidual cell reaction. II. Peak of sensitivity to decidual cell reaction in lactogenic hormone treated rats under rhythmical and permanent illumination. Acta endocr., Copenh. 47, 314. 